\title{
Could sublingual vaccination be a viable option for the prevention of recurrent urinary tract infection in Canada? A systematic review of the current literature and plans for the future
}

\author{
J. Curtis Nickel, MD, FRCSC', Paula Saz-Leal, PhD', R. Christopher Doiron, MD'
}

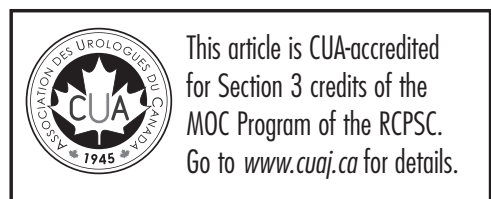

'Department of Urology, Queen's University, Kingston, ON, Canada; ${ }^{2}$ Inmunotek S.L., Alcalá de Henares, Madrid, Spain

Cite as: Can Urol Assoc J 2020;14(8):281-7. hitp://dx.doi.org/10.5489/cuaj.6690

\section{Abstract}

Introduction: We conducted a systematic review to examine the role of a novel sublingual vaccine - Uromune - for prevention of recurrent urinary tract infection ( $\mathrm{rUTI}$ ) to understand its potential role for Canadian women suffering from rUTI.

Methods: Databases were searched for studies published from 2010 2020 that investigated use of Uromune in the management of rUTI. Only original clinical studies that included use of Uromune as prophylaxis for uncomplicated rUTI in women that included UTI-free rate following initiation of vaccine as an outcome were included. Results: Of 73 publications related to Uromune and UTIs, 19 unique clinical studies were identified evaluating Uromune for prevention of rUTI. Five studies met our inclusion criteria for primary review. These included 1408 women treated with Uromune. In two retrospective comparative studies, subjects treated with Uromune daily for three months (519 women in total) had significantly higher UTI-free rates (35-90\%) than subjects treated with six months of antibiotic prophylaxis ( $0 \%$ in 499 women in total) over 15 months ( $p<0.001$ for both studies). In three prospective, uncontrolled studies, UTI-free rates for subjects treated with Uromune ranged from $33-78 \%$ over 9-24 months. No major safety issues were identified in these trials. Additional unique studies evaluating Uromune for rUTI that did not meet our criteria added consistent confirmation of the potential effectiveness and safety of Uromune to prevent rUTI. Conclusions: Although these findings require confirmation in currently active, prospective clinical studies, including a randomized placebo-controlled trial, Uromune may be an alternative to antibiotics to prevent rUTI in Canadian women.

\section{Introduction}

The management, both treatment and prevention, of recurrent urinary tract infection ( $\mathrm{rUTI}$ ) in women involves the use of antibiotics. Antibiotics are typically prescribed for 3-7 days for each acute episode and six weeks to six months for prophylaxis. They are also prescribed for self-start treatment and post-coital dosing in sexually active females. ${ }^{1}$
Approximately 50-60\% of women experience a UTI in their lifetime, ${ }^{2}$ with $>25 \%$ developing $\mathrm{rUTI}$, requiring multiple short- and long-term dosing of antibiotics. ${ }^{3}$ In Canada, this represents an exorbitant amount of antibiotics - a significant cost and burden to both society and patients. ${ }^{4}$

rUTI is defined as $\geq 3$ episodes of UTI within the last 12 months or $\geq 2$ episodes within six months. ${ }^{1}$ The primary therapy for these patients comes with a price. Typical side effects with first-line antibiotics include gastric upset, rash, and other allergic reactions or intolerances with sulfamethoxazole-trimethoprim (TMP-SMX), fluoroquinolones, and nitrofurantoin. Furthermore, more serious and even life-threatening consequences, such as toxic epidermal necrolysis and Stevens-Johnson Syndrome with TMP-SMX; potential neurotoxicity and liver/lung autoimmune disease with nitrofurantoin; and $C$. difficile infection, the musculoskeletal/neurological/psychiatric triad, and aorta rupture/ tearing with fluoroquinolones should make practitioners think twice about prolonged antibiotic treatments for $\mathrm{rUTI} .{ }^{5,6}$

The Public Health Agency of Canada provides surveillance reports for attributable costs and mortality associated with UTIs and the figures are staggering. ${ }^{7}$ The rapidly rising antibiotic resistance rates for uropathogens, attributed mostly to the widespread use of antibiotics to treat and manage UTI, is exacerbating this problem. The Canadian Council of Academies has estimated that in 2018,, ${ }^{8}$ approximately $23.9 \%$ of UTIs in Canada were resistant to drugs generally used to treat them, costing the Canadian healthcare system approximately 350 million dollars with 6700 deaths and 3000 years of lost employment.

UTI represents one of the most common causes of infection requiring antibiotics (second only to skin and soft tissue infection) and, therefore, one of the most common causes of increasing bacterial resistance in our communities. Antibiotic stewardship is a worthy goal but the non-antibiotic alternatives (cranberry extract, D-Mannose, probiotics, etc.) appear to provide only marginal benefit in preventing rUTI. ${ }^{1,3,9}$ The stated priority of Health Canada ${ }^{10}$ is to incentiv- 
ize innovation for human antimicrobial products, including the advancement and development of antibiotic candidates, non-traditional therapeutics, and/or biologics/vaccines. A recent systematic review on the role of vaccines for $\mathrm{rUTI}^{11}$ concluded that vaccines seem to have an increasing role in the prevention of rUTI with tolerable side effects, however, more work needs to be done, including inclusion of other high-risk patient groups.

Uromune (Red Leaf Medical, Canada/Inmunotek S.L., Spain), a bacterial mucosal rUTI vaccine in the form of a sublingual spray, is currently pre-licensed in phase 3 development stage, available under the named patient programs (e.g., compassionate use) in 26 countries worldwide (such as the U.K., New Zealand, Netherlands, Germany, Spain, and many other Western European countries). Efforts are underway to make Uromune available to Canadian patients (at present time, Canadian women cannot access this product).

The vaccine is a glycerinated suspension of whole-cell, heatinactivated bacteria, including equal amounts of four common UTI-causing pathogens: Escherichia coli; Klebsiella pneumoniae; Proteus vulgaris; and Enterococcus faecalis (MV140 formulation). There are several European studies examining the impact of Uromune on rUTI in various populations of patients. Most are uncontrolled and retrospective studies, but there are enough evaluation studies, some with an antibiotic prophylaxis comparator, to examine the potential benefits of Uromune with respect to reducing the risk of rUTI in women.

We systemically reviewed the role of Uromune in the prevention of rUTI in an attempt to understand its potential role for Canadian women suffering from this condition.

\section{Methods}

\section{Search strategy}

The search strategy for this systematic review was conducted to find all abstracts and publications relevant to the specific vaccine (Uromune or MV140) and rUTI. Search terms included: "urinary tract infection" or "recurrent urinary tract infection" or "UTI" and "Uromune" or "sublingual vaccine" or "sublingual vaccination" or "mucosal stimulation" or "mucosal vaccination" or "MV140".

Databases EMBASE and MEDLINE were searched for publications published January 1, 2010 to March 31, 2020. Authors JCN and RCD cross-checked selected studies. References from identified studies were also screened for additional relevant publications. The published proceedings of international urology, urogynecology, microbiology and infectious diseases meetings held between 2010 and 2020 that included any reference to Uromune were further reviewed via Inmunotek's prospectively maintained database of meeting presentations.

\section{Inclusion and exclusion criteria}

Only original clinical studies that included the use of Uromune as treatment for uncomplicated rUTI in women were included. Female subjects must have met the definition of rUTI and trials must have reported UTI-free rate following initiation of the vaccine as an outcome. Non-original articles, case reports, reviews, and non-clinical articles were excluded, while studies that examined men only, included only complicated UTI, or included pediatric subjects were also excluded from the review.

\section{Data extraction}

Data extraction from articles/abstracts identified for the primary analysis was carried out by two authors (JCN and RCD) and checked by the third author (PSL); the final report represented mutual consensus. Studies written in Spanish were translated by one of the authors (PSL). Data collected included type and date of study publication/presentation, subject population demographics (including age and gender), adherence to rUTI definition, duration of vaccine administration, duration of followup, and rUTI outcomes. The primary outcome for this evaluation was the reported UTI-free rate after administration of the vaccine. Secondary outcomes included safety, change in frequency of UTI, time to first UTI, and comparator

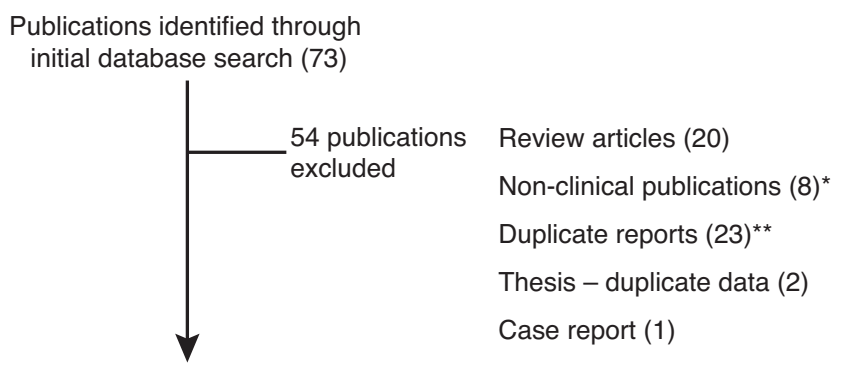

Potential clinical studies (19)

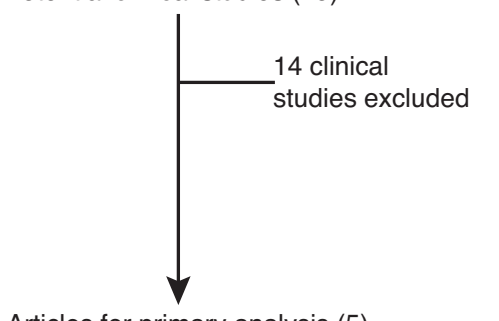

Complicated UTI (10)

Prostatitis or men (3)

Children (1)

Articles for primary analysis (5)

*Non-clinical publications include original basic research studies with Uromune, as well as mechanism reviews in the field.

** Duplicate reports represented published study abstracts that reported results from the same cohort of subjects. The final published abstracts and/or journal publications from these studies were included as potential study articles.

Fig. 1. Flow chart of literature search and included studies. 
analyses. A quality analysis of included articles was carried out using the Newcastle-Ottawa Scale. ${ }^{12}$

\section{Results}

\section{Identification of studies}

A total of 73 articles and/or presentation abstracts related to the use of Uromune for UTI were found. After excluding duplicate studies and those that were not related to the clinical evaluation of Uromune, 19 studies evaluating Uromune for the prevention of rUTI remained (Fig. 1). Five studies that met our inclusion criteria were included in the primary review. Fourteen studies that examined the impact of Uromune in subjects with rUTI but did not fully comply with our inclusion criteria (e.g., complicated rUTI, male population, etc.) were further evaluated in a secondary review (one study in the primary analysis included men and women with rUTI with separate gender-specific analyses available).

\section{Prevention of uncomplicated rUTI in women}

In review of the five studies that met inclusion criteria, a total of 1408 female subjects with rUTI were treated with Uromune and 499 with antibiotic prophylaxis as a control group (Table 1). Included in the five studies were two retrospective $^{13,14}$ and three prospective cohort studies. ${ }^{15-17}$ None of the studies were randomized or placebo-controlled and the heterogeneous design of the five included studies pre- cluded a formal meta-analysis. In all five studies, female subjects with rUTI received sublingual Uromune vaccination daily for three months. Two of the studies ${ }^{13,14}$ included a comparator group treated with six months of antibiotic prophylaxis. One study ${ }^{16}$ enrolled both women and men with rUTI (women with rUTI analyzed separately), while another included women with uncomplicated and complicated rUTI. ${ }^{17}$ Whole study periods ranged from nine months ${ }^{16}$ to 24 months,${ }^{17}$ while the average age enrolled ranged from 47.7 years ${ }^{15}$ to 73.5 years. $^{16}$ (Table 1 ).

The study by Lorenzo-Gómez et $\mathrm{a}^{13}$ was a retrospective, observational evaluation of 159 women with rUTI treated with three months of Uromune compared to 160 similar women who were managed with six months of SMX-TMP prophylaxis. At all time points, the UTI-free rate in the Uromune group was significantly higher than in the antibiotic group; at the end of the study period (15 months), 34.6\% $(n=55)$ of the women who had received Uromune were UTIfree compared to 0 women who had antibiotic prophylaxis $(p<0.001)$. In a further retrospective comparative cohort study, ${ }^{14} 90.3 \%$ ( $\left.n=325\right)$ of 360 women with rUTI treated with Uromune were UTI-free at the end of the 12-month followup period. This was in contrast to the 339 women managed with either six months of SMX/TMP or nitrofurantoin prophylaxis, of whom 0 were reported to be UTI-free at 12-months of followup $(p<0.001)$. Yang et $\mathrm{al}^{15}$ prospectively followed 75 women out of 77 who started Uromune therapy for rUTI and observed a $78.7 \%(n=59)$ UTI-free rate at 12 months from initiation of the treatment. A study reported by RamírezSevilla et $\mathrm{al}^{16}{ }^{16}$ which evaluated rUTI in male and female

\begin{tabular}{|c|c|c|c|c|c|c|}
\hline Study & Date & $\begin{array}{l}\text { Treatment } \\
\text { (duration) }\end{array}$ & $\begin{array}{c}\text { Eligible } \\
\text { subjects (n) }\end{array}$ & $\begin{array}{l}\text { Age years } \\
\text { (range) }\end{array}$ & $\begin{array}{l}\text { Study period } \\
\text { (months)* }\end{array}$ & $\begin{array}{l}\text { UTI-free rate \% }(n) \text { at } \\
\text { indicated timepoints }\end{array}$ \\
\hline \multirow[t]{2}{*}{ Lorenzo-Gómez et al ${ }^{13}$} & 2013 & $\begin{array}{l}\text { Uromune } \\
\text { (3 months) }\end{array}$ & 159 & $\begin{array}{c}47.7 \\
(16-85)\end{array}$ & $\begin{array}{c}3 \\
9 \\
15\end{array}$ & $\begin{array}{c}63.5(101)^{* * *} \\
56.6(90)^{* * *} \\
34.6(55)^{* * *}\end{array}$ \\
\hline & & $\begin{array}{l}\text { SMX/TMP } \\
\text { (6 months) }\end{array}$ & 160 & $\begin{array}{c}48.1 \\
(16-87)\end{array}$ & $\begin{array}{c}3 \\
9 \\
15\end{array}$ & $\begin{array}{c}5.6(9) \\
2.5(4) \\
0(0)\end{array}$ \\
\hline \multirow[t]{2}{*}{ Lorenzo-Gómez et al ${ }^{14}$} & 2015 & $\begin{array}{l}\text { Uromune } \\
\text { (3 months) }\end{array}$ & 360 & $\begin{array}{c}60 \\
(44-70)\end{array}$ & $12^{* *}$ & $90.3(325)^{* * *}$ \\
\hline & & $\begin{array}{l}\text { SMX/TMP or } \\
\text { nitrofurantoin } \\
\text { (6 months) }\end{array}$ & 339 & $\begin{array}{c}59 \\
(49-59)\end{array}$ & $12^{* *}$ & $0(0)$ \\
\hline Yang et $\mathrm{al}^{15}$ & 2018 & $\begin{array}{l}\text { Uromune } \\
\text { (3 months) }\end{array}$ & 75 & $\begin{array}{c}56 \\
(18-87)\end{array}$ & 12 & 78.7 (59) \\
\hline Ramírez-Sevilla et al ${ }^{16}$ & 2019 & $\begin{array}{l}\text { Uromune } \\
\text { (3 months) }\end{array}$ & 648 & $\begin{array}{c}73.5 \\
(19-97)\end{array}$ & $\begin{array}{l}3^{* *} \\
6^{* *}\end{array}$ & $\begin{array}{l}45.4(294) \\
32.7(212)\end{array}$ \\
\hline Carrión-López et al ${ }^{17}$ & 2020 & $\begin{array}{l}\text { Uromune } \\
\text { (3 months) }\end{array}$ & 166 & $\begin{array}{c}62.3 \\
(19-89)\end{array}$ & $\begin{array}{c}3 \\
6 \\
12 \\
24\end{array}$ & $\begin{array}{c}74.4(124) \\
68.1(113) \\
52.4(87) \\
44.5(43 / 96)\end{array}$ \\
\hline
\end{tabular}

All subjects were treated for 3 months with Uromune (and in 2 studies 6 months of antibiotic prophylaxis) with a total study period from initiation of treatment ranging from 9-24 months. *Unless otherwise specified, timepoint since initiation of the treatment. **Followup period that begins after completion of vaccination. ${ }^{* * *}$ p $<0.0001$ comparing Uromune group to group receiving prophylactic antibiotics. rUTI: recurrent urinary tract infection; SXM/TMP: trimethoprim/sulfamethoxazole. 
subjects treated with Uromune, included 648 females (84\% of the study population). They reported a UTI-free rate in the female subjects of $45.4 \%(n=294)$ at three-month followup, which dropped to $32.7 \%(\mathrm{n}=212)$ at six months. A study by Carrión-Lopez et al ${ }^{17}$ included 166 female subjects, 53.6\% categorized as uncomplicated UTI. The rest of the cohort had associated risk factors. The UTI-free rate for the entire group was $74.4 \%(n=124)$ at three months after initiating vaccination, $68.1 \%(n=113)$ at six months, and $52.4 \%(n=87)$ at 12 months. Of the 96 subjects followed for 24 months, the UTI-free rate was $44.5 \%(n=43)$. They reported that the mean time to first UTI in uncomplicated rUTI subjects was longer if the patients had no UTI risk factors compared to those with identified risk factors (13.9 months vs. 11.2 months; $\mathrm{p}=0.048$ ). Those with uncomplicated UTIs had fewer rUTI after vaccination compared to those with complicated UTIs (coefficient $\beta \quad 0.40 ;-0.8$ to $-0.14 ; p=0.015)$. The reliability for reporting secondary effectiveness outcomes - UTI rate in previous year, time to first UTI, and UTI frequency during and after Uromune treatment - was so inconsistent that these variables could not be accurately compared between the five studies.

\section{Safety assessment in women with uncomplicated UTI}

The overall safety data from these five studies did not indicate any major safety concerns. There were no adverse events reported for the two major comparative studies, ${ }^{13,14}$ one serious adverse event (allergic reaction) and seven minor adverse events (post-nasal drip, stinging around mouth, pruritus over old BCG scar, pruritus over abdomen, intermittent abdominal pain, mild nausea, and exacerbation of underlying asthma) in the U.K. prospective study. ${ }^{15}$ Only minor side effects were reported in the two remaining studies. These minor side effects included in one study ${ }^{16}$ were dry mouth in eight subjects, gastritis in four, and general illness in four. Other minor side effects included were two reports of mild glossitis and one flareup of rheumatoid arthritis, which was not believed to be associated with treatment. ${ }^{17}$

\section{Assessment of study quality}

Results from the assessment of study quality using the Newcastle-Ottawa Scale ${ }^{12}$ are shown in Table 2. All studies were open-label and non-blinded. Three of the five studies were prospective in nature and did not include a comparator group, while two were retrospective comparator studies that included a control group treated with prophylactic antibiotics. Recruitment into most of the studies was unclear, while followup was at least 12 months in 4/5 studies, and six months in one study. The studies selected for review appeared to enroll females with an accepted diagnosis of rUTI and all had at least one major common reported outcome - UTI-free rate - during the followup period. The definition of UTI-free status (symptoms, culture, or both) was, however, unclear. Overall, the five studies would be considered level III evidence, with significant potential for reporting bias.

\section{Prevention of rUTl in other populations}

A number of studies evaluated the impact of Uromune on rUTI in populations that did not include (or differentially analyzed) women with uncomplicated rUTI but rather included studies that enrolled men, children, the frail elderly, or subjects with complicated UTI. Of the 784 subjects enrolled by Ramírez-Sevilla et al, ${ }^{16} 136$ were men who experienced a $38 \%$ and $30 \%$ UTI-free rate at three- and six-month followup, respectively. Yang et $\mathrm{al}^{18}$ described 14 men with rUTI treated with three months of Uromune followed for a total of 12 months and reported a UTI-free rate of $71 \%$ (10/14). Arce et $\mathrm{al}^{19}$ presented a study of 58 men and women (unknown ratio) with rUTI treated with Uromune for three months and followed for a total of nine months and observed an overall UTI-free rate of $50 \%$ at three months, $44.8 \%$ at six months, and $37.9 \%$ at nine months following initiation of the treatment.

Other studies evaluating subjects (men and/or women) with complicated UTI, including men with prostatitis, ${ }^{20}$ neurogenic bladder, ${ }^{21}$ autoimmune disease and treatment-mediated immunosuppressed patients, ${ }^{22}$ chronic renal disease and kidney transplant, ${ }^{23-26}$ lymphoproliferative disorders, ${ }^{27}$ frail elderly, ${ }^{28,29}$ children, $^{30}$ and post-surgery, ${ }^{31}$ consistently reported favorable UTI-free rates ranging from $30-50 \%$, significant UTI reduction rates after Uromune treatment, and/ or improved quality of life (Table 3). Moreover, one study addressed that re-vaccination a year-and-a-half later, as well as being safe, may confer further benefit to individuals with rUTI. ${ }^{29}$ The studies either did not report adverse events and/ or observed no safety issues in respect to Uromune therapy.

\begin{tabular}{|c|c|c|c|c|}
\hline Study & Selection & Comparability & Outcome & Total \\
\hline Lorenzo-Gómez et al $(2013)^{13}$ & $4 / 4$ & $0 / 2$ & $3 / 3$ & $7 / 9$ \\
\hline Lorenzo-Gómez et al (2015) ${ }^{14}$ & $4 / 4$ & $0 / 2$ & $3 / 3$ & $7 / 9$ \\
\hline Yang et al $(2018)^{15}$ & $3 / 4$ & $\mathrm{~N} / \mathrm{A}$ & $3 / 3$ & $6 / 9$ \\
\hline Ramírez-Sevilla et al $(2019)^{16}$ & $3 / 4$ & $\mathrm{~N} / \mathrm{A}$ & $2 / 3$ & $5 / 9$ \\
\hline Carrión-López et al $(2020)^{17}$ & $3 / 4$ & N/A & $3 / 3$ & $6 / 9$ \\
\hline
\end{tabular}




\begin{tabular}{|c|c|c|c|c|}
\hline Study & Date & Subject population (n) & Study period (months)* & $\begin{array}{l}\text { Pertinent observations/findings at indicated time } \\
\text { points }\end{array}$ \\
\hline $\begin{array}{l}\text { Ramírez-Sevilla } \\
\text { et } \text { al }^{16}\end{array}$ & 2019 & Men (136) & $6 * *$ & $\begin{array}{l}\text { 3-mo followup: } 38.2 \% \text { UTI-free rate (men) } \\
\text { 6-mo followup: } 30.1 \% \text { UTI-free rate (men) }\end{array}$ \\
\hline Yang et $\mathrm{al}^{18}$ & 2017 & Men (14) & 12 & $71 \%(10 / 14)$ UTI-free rate \\
\hline Arce et al ${ }^{19}$ & 2013 & Men and women (58) & 9 & $\begin{array}{l}\text { 3-mo: } 50 \% \text { UTI-free rate (all) } \\
\text { 6-mo: } 44.8 \% \text { UTI-free rate (all) } \\
\text { 9-mo: } 37.9 \% \text { UTI-free rate (all) }\end{array}$ \\
\hline $\begin{array}{l}\text { Lorenzo-Gómez } \\
\text { et } \mathrm{al}^{20}\end{array}$ & 2018 & $\begin{array}{l}\text { Men with prostatitis } \\
\text { (100:50 in each group) }\end{array}$ & 15 & $\begin{array}{c}\text { Uromune }+ \text { bromazepam }+ \text { Serenoa repens vs. } \\
\text { Bromazepam }+ \text { Serenoa repens } \\
\text { Improved quality of life compared to control group at } \\
3,9 \text {, and } 15 \text { months }(p<0.0001)\end{array}$ \\
\hline $\begin{array}{l}\text { Ordaz-Jurado } \\
\text { et } \mathrm{al}^{21}\end{array}$ & 2014 & $\begin{array}{l}\text { Neurogenic bladder } \\
\text { (14 men; } 3 \text { women) }\end{array}$ & 12 & $\begin{array}{c}\text { Decrease in UTI rate } \\
\text { Median } 4 \text { (range } 1-12) / y \text { previous to } 0(\text { range } 0-3) / y r \\
\text { after vaccination }(p=0.9)\end{array}$ \\
\hline $\begin{array}{l}\text { Sánchez-Ramón } \\
\text { et } \mathrm{al}^{22}\end{array}$ & 2020 & $\begin{array}{l}\text { Autoimmune disease } \\
\text { and immunosuppression } \\
\text { treatment (38) }\end{array}$ & 12 & $\begin{array}{l}\text { Significant decrease in UTI rate from } 5.57 \pm 8.41 / \mathrm{yr} \\
\text { before to } 1.0 \pm 1.28 / \mathrm{yr} \text { after vaccination }(\mathrm{p}<0.05)\end{array}$ \\
\hline $\begin{array}{l}\text { García-Agudo } \\
\text { et } \mathrm{al}^{23}\end{array}$ & 2015 & $\begin{array}{l}\text { Chronic renal disease } \\
\text { ( } 21 \text { women; } 5 \text { men) }\end{array}$ & 6 & $\begin{array}{c}19.2 \% \text { UTI-free rate } \\
\text { Significant decrease in UTI from } 3.62 \pm 1.77 / 6 \text { mo } \\
\text { previous to } 1.69 \pm 1.62 / 6 \text { mo after vaccination }\end{array}$ \\
\hline $\begin{array}{l}\text { García-Ledesma } \\
\text { et } \mathrm{al}^{24}\end{array}$ & 2016 & $\begin{array}{l}\text { Chronic renal disease } \\
\text { including } 23 \% \text { transplant } \\
\text { (12 women; } 1 \text { man) }\end{array}$ & 12 & $\begin{array}{c}\text { Significant decrease in UTI Mean from } 5.8 \pm 2.4 / \mathrm{yr} \text { prior } \\
\text { to } 1.7 \pm 2.6 / \mathrm{yr} \text { after vaccination }\end{array}$ \\
\hline $\begin{array}{l}\text { Castro-Alonso } \\
\text { et } \mathrm{al}^{25}\end{array}$ & 2016 & $\begin{array}{l}\text { Chronic renal disease } \\
\text { ( } 25 \text { women; } 7 \text { men) }\end{array}$ & 6 & $\begin{array}{l}43.8 \% \text { UTI-free rate } \\
\text { Significant decrease in UTI from } 2.63 \pm 5.54 / 6 \text { mo } \\
\text { previous to } 0.9 \pm 0.8 / 6 \text { mo after vaccination }(p<0.001)\end{array}$ \\
\hline Shabaka et $a^{26}$ & 2018 & Renal transplant (43) & $\begin{array}{l}12 \\
\text { (6-month Uromune } \\
\text { vaccination) }\end{array}$ & $\begin{array}{c}16.3 \% \text { UTI-free } \\
\text { UTI rate (mean) from } 4.2 / \mathrm{yr} \text { previous to } 2.7 / \mathrm{yr} \text { after } \\
\text { vaccination }(40 \% \text { reduction; } \mathrm{p}<0.001 \text { ) }\end{array}$ \\
\hline $\begin{array}{l}\text { Ochoa-Grullón } \\
\text { et } \mathrm{al}^{27}\end{array}$ & 2017 & $\begin{array}{l}\text { Lympho-proliferative } \\
\text { disorder } \\
\text { (14 women; } 4 \text { men) }\end{array}$ & 12 & $\begin{array}{c}\text { Significant decrease in UTI rate from } 4.6 \pm 1.8 / \mathrm{yr} \text { before } \\
\text { to } 1.22 \pm 0.44 / \mathrm{yr} \text { after vaccination }(p<0.0001)\end{array}$ \\
\hline $\begin{array}{l}\text { Lorenzo-Gómez } \\
\text { et } \mathrm{al}^{28}\end{array}$ & 2018 & $\begin{array}{l}\text { Frail elderly } \\
\text { (50: } 28 \text { women; } 22 \text { men in } \\
\text { each group) }\end{array}$ & Unclear & $\begin{array}{l}\text { Uromune vs. antibiotic prophylaxis } \\
\text { Reduced UTI average/mo }(0.212 \pm 0.14) \text { compared to } \\
\text { antibiotic group }(0.66 \pm 0.31(p<0.0213)\end{array}$ \\
\hline $\begin{array}{l}\text { Padilla- } \\
\text { Fernández et } \mathrm{al}^{29}\end{array}$ & 2019 & $\begin{array}{c}\text { Frail elderly } \\
\text { (60 women; } 10 \text { men) }\end{array}$ & $\begin{array}{l}\text { 1st vaccination: } \\
6 \text { mo }\end{array}$ & $\begin{array}{l}\text { women } 1 \mathrm{st}(\mathrm{n}=60), 17.3 \text {-fold reduction of UTI rate } \\
\text { men } 1 \mathrm{st}(\mathrm{n}=10), 12.27 \text {-fold reduction of UTI rate }\end{array}$ \\
\hline & & & $\begin{array}{l}\text { Boost (new 3-mo course } \\
1.5 \text { yr later): } 6 \text { mo }\end{array}$ & $\begin{array}{l}\text { women boost }(n=60), 12.42 \text {-fold decreased UTI rate } \\
\text { men boost }(n=10), 14.6 \text {-fold decreased UTI rate }\end{array}$ \\
\hline $\begin{array}{l}\text { Martínez- } \\
\text { Camacho et al }\end{array}$ & 2015 & $\begin{array}{l}\text { Children with urological/renal } \\
\text { complications ( } 3 \text { female) }\end{array}$ & $12-18$ & $\begin{array}{c}\text { Reduced UTI rate (one UTI-free; one asymptomatic } \\
\text { bacteriuria; one E. coli-causing UTI) }\end{array}$ \\
\hline $\begin{array}{l}\text { Lorenzo-Gómez } \\
\text { et } \mathrm{al}^{31}\end{array}$ & 2015 & $\begin{array}{c}\text { Females after transobturator } \\
\text { tape surgery } \\
(420 ; 60 \text { with rUTI) }\end{array}$ & 12 & $\begin{array}{l}82 \% \text { overall UTI-free rate } \\
\text { No clarity on Uromune impact } \\
\text { (no analysis of rUTI subjects) }\end{array}$ \\
\hline
\end{tabular}

\section{Discussion}

The prevention of rUTI in women remains a significant healthcare issue despite seemingly effective antibiotic therapy. ${ }^{2,4}$ Infection recurs after antibiotic treatment, even long-term antibiotic prophylaxis..$^{1,3}$ Continued use of antibiotics for this condition causes side effects in treated women and measurable costs to society, ${ }^{2,4}$ while contributing to the frightening scenario of increasing antibiotic resistance. ${ }^{7,8}$
Most of the non-antibiotic options available have not proven effective. ${ }^{9}$ A recent evaluation of the role of vaccines for $\mathrm{rUTI}$ included Uromune (sublingual spray), OM-89/UroVaxom (oral tablet), Solco-Urovac (vaginal suppository/intramuscular injection), and ExPEC4V (intramuscular injection). ${ }^{11}$ The assessment concluded that overall vaccine therapy seemed to be efficacious at six months (odds ratio [OR] 0.17; 95\% confidence interval [CI] 0.006-0.50) compared to comparator or placebo, with Uromune demonstrating superior 
outcomes. The overall efficacy remained significant at 12 months (OR 0.20; 95\% Cl 0.07-0.59). However, if Uromune was removed from the analysis, efficacy was no longer significant (OR 0.66; 95\% Cl 0.35-1.26).

Our comprehensive, systematic review of the world literature indicates that Uromune may benefit women suffering from uncomplicated rUTI by increasing the probability of UTI-free status and/or reducing the frequency of UTI. Studies showing this possibility included retrospective ${ }^{13,14}$ and prospective studies, ${ }^{15-17}$ but they were not controlled and did not compare the UTI-free rate of patients treated with Uromune with a placebo. However, all five studies ${ }^{13-17}$ selected reported the UTI-free rate after initiation of Uromune in women with rUTI, a clinically valid outcome. The impact of Uromune compared to antibiotic prophylaxis was evaluated in two large studies ${ }^{13,14}$ and both showed a clear superiority of Uromune compared to long-term antibiotics. But again, even the design of these studies with a comparator group was not prospective or randomized.

Despite the limitations of these studies, the evidence does suggest that Uromune appears to be effective, even more so than antibiotic prophylaxis, in achieving UTI-free status in women suffering from rUTI. In this population of women with uncomplicated rUTI, there was an excellent safety profile with Uromune therapy. Compilation of safety issues in the five included studies bring up mostly mild adverse reactions in $1.7 \%$ of total subjects. Moreover, only two of 1407 women treated with Uromune in these selected studies decided to discontinue the treatment. The overall safety of Uromune is confirmed with safety reports from over 20500 subjects receiving Uromune in the 2014-2020 period in compassionate or named patient programs (ClinicalTrial. Gov: NCT 04173013). Only eight reports of adverse reactions have been filed for over 1.5 million doses (data on file, Pharmacovigilance Department, Inmunotek, Spain).

While only five studies met our criteria of including uncomplicated rUTI in women, we noted 14 unique studies evaluating Uromune in other populations of patients suffering from rUTI. In men, elderly, children, and those with complicated UTIs (neurogenic bladders, immunological disorders, renal disease [including those with kidney transplant], immunological disease, and post-surgery), Uromune seems to provide a safe alternative to antibiotics to reduce risk of UTI among populations other than women with uncomplicated rUTI. These studies, which did not meet our inclusion criteria, while poorly designed and reported, add further confirmation of the potential safety and clinical benefits of Uromune. Moreover, re-vaccination may confer further clinical benefit and it is anticipated that future studies will evaluate the safety and efficacy of repeated doses of the vaccine if it appears the beneficial impact decreases over time.

Uromune is a sublingual spray that consists of a suspension of whole-cell, heat-inactivated bacteria: Escherichia coli;
Klebsiella pneumoniae; Proteus vulgaris; and Enterococcus faecalis (MV140 formulation). The sublingual route of immunization is gaining interest compared to other mucosal routes, as it has been shown to avoid degradation by gastric fluids and gastrointestinal enzymes and has the potential to induce mucosal immune responses in a broad range of tissues, including the genitourinary tract. ${ }^{32,33}$ Dissemination of immunity to the effector site, the bladder mucosa, is possible via the migration of lymphocytes and other immune cells from the inductor site, the sublingual mucosa, via the mucosal associated lymphoid tissue. ${ }^{34}$ In this regard, studies have shown ${ }^{35,36}$ that stimulation of the sublingual mucosa with Uromune induces immune responses both systemically and at the level of the genitourinary tract. This response comprises the induction of a T-cell-specific adaptive immune response, as well as of the innate immune system. This is the mechanism of action postulated for this sublingual vaccination strategy.

Although the evidence evaluated in this report may not be sufficient for the product to obtain Health Canada regulatory approval for an indication to manage uncomplicated rUTI in women, it does suggest that it might be appropriate for it to be available on a compassionate, patient-by-patient basis with stringent followup reporting. A prospective Health Canada and Queen's University IRB-approved early clinical practice experience study is presently underway (unfortunately impacted by the 2020 COVID-19 pandemic) in Kingston, Ontario, Canada to assess the benefits and safety of Uromune in real-world Canadian practice (ClinicalTrial. gov: NCT04096820).

Furthermore, the ultimate assessment of efficacy and safety will come from a European randomized placebocontrolled trial (ClinicalTrial.gov: NCT02543827) that is presently nearing completion. If this trial confirms the findings and conclusion of our systematic review, then women with rUTI should be hopeful that a vaccine may be available in Canada in the near future. Such a strategy will be good for Canadian women suffering from rUTI and will result in better antibiotic stewardship for Canada.

\section{Conclusions}

The novel sublingual spray vaccine, Uromune, appears to be a safe and effective alternative to repeated or long-term dosing of antibiotics to prevent rUTI in Canadian women.

Competing interests: Dr. Nickel has been a consultant for Alivio, Farr Labs, Inmunotek, Kanglaite, MicroGenDx, Redleaf Medical, Seikagaku Corp, TEVA, Urogen Pharma, and Valensa Int; has participated in scientific studies/trials supported by CIHR, Inmunotek, MicroGenDx, NIH, and Redleaf Medical; and is the Editor of AUA Update Series. Dr. Saz-Leal is an employee of Inmunotek. Dr. Doiron reports no competing personal or financial interests related to this work.

This paper has been peer-reviewed 


\section{References}

1. Anger J, Lee U, Ackerman AL. Recurrent uncomplicated urinary tract infections in women: AUA/CUA/SUFU guideline. J Urol 2019;202:282-9. https://doi.org/10.1097/JU.0000000000000296

2. Foxman $B$, Barlow R, $D^{\prime}$ Arcy $H$, et al. Self-reported incidence of urinary tract infection and associated costs. Ann Epidemiol 2000;10:509-15. https://doi.org/10.1016/S1047-2797(00)00072-7

3. Epp A, Larochelle. ASOGC clinical guidelines for rUTI. J Obstet Gynaecol Can 2017;39:e422-31. https://doi.org/10.1016/i.jogc.2017.08.017

4. Wagenlehner F, Wullt B, Ballarini $S$, et al. Social and economic burden of recurrent urinary tract infections and quality of life: A patient web-based study (GESPRIT). Expert Rev Pharmacoecon Outcomes Res 2018;18:107-17. https://doi.org/10.1080/14737167.2017.1359543

5. Cunha B. Antibiotic side effects. Med Clin North Am 2001;85:149-85. hitps://doi.org/10.1016/S0025-7125(05)70309-6

6. Nickel J C, Doiron R C. Dangerous fluoroquinolones: The urologist's dilemma. Can Urol Assoc J 2020; 14:856. https://doi.org/10.5489/cuai.6498

7. When antibiotics fail: The Expert Panel on the potential socio-economic impacts of antimicrobial resistance in Canada 2019. Available at: https://cca-reports.ca/reports/the-potential-socio-economic-impacts-ofantimicrobial-resistance-in-canada/. Accessed April 14, 2020.

8. CADTH, Public Health Agency of Canada. Canadian context on antimicrobial resistance, 2018. Available at: https://www.cadth.ca/sites/default/files/symp-2018/presentations/april17-2018/ConcurrentSession-E6-Antimicrobial-Resistance-Drugs.pdf. Accessed April 14, 2020

9. Hickling D, Nickel JC. Management of acute cystitis in women without antibiotics. AUA Update Series 2019;38:52-8

10. Galand L. AMR and Innovation: The regulator's prospective. Bureau of Gastroenterology, Infection and viral disease, Therapeutics Products Directorate, Health Canada, 2018. Available at: hittps://www.cadth. ca/sites/default/files/symp-2018/presentations/april17-2018/Concurrent-Session-E6-AntimicrobialResistance-Drugs.pdf. Accessed April 14, 2020

11. Prattley S, Geraghty R, Moore M. Role of vaccines for recurrent urinary tract infections: A systematic review. Eur Urol Focus 2019:S2405-4569.

12. Wells $G A$, Shea $B, O^{\prime}$ Connell $D$, et al. The Newcastle-Ottawa Scale (NOS) for assessing the quality of non-randomized studies in meta-analyses. Available at hittp://www.ohri.ca/programs/dinical_epidemiology/oxford.asp. Accessed April 19, 2020

13. Lorenzo-Gómez MF, Padilla-Fernandez B, Garcia-Cenador MB, et al. Comparison of sublingual therapeutic vaccine with antibiotics for the prophylaxis of recurrent urinary tract infections. Front Cell Infect Microbiol 2015;5:50. https://doi.org/10.3389/fcimb.2015.00050

14. Lorenzo-Gómez MF, Padilla-Fernandez B, Garcia-Criado FJ, et al. Evaluation of a therapeutic vaccine for the prevention of recurrent urinary tract infections vs. prophylactic treatment with antibiotics. Int Urogynecol J 2013;24:127-34. https://doi.org/10.1007/s00192-012-1853-5

15. Yang $B$, Foley $S$. First experience in the UK of treating women with recurrent urinary tract infections with the bacterial vaccine Uromune ${ }^{\circledR}$. BJU Int 2018;121:289-92. https://doi.org/10.1111/bju.14067

16. Ramirez Sevilla C, Gomez Lanza E, Manzanera JL, et al. Active immunoprophylaxis with Uromune ${ }^{\circledR}$ decreases the recurrence of urinary tract infections at three and six months after treatment without relevant secondary effects. BMC Infect Dis 2019;19:901. https://doi.org/10.1186/s12879-019-4541-y

17. Carrion-Lopez P, Martinez-Ruiz J, Libran-Garcia L, et al. Analysis of the efficacy of a sublingual bacterial vaccine in the prophylaxis of recurrent urinary tract infection. Urol Int 2020:1-8.

18. Yang B, Foley $S$. The first experience in the United Kingdom of using the novel treatment Uromune in men with recurrent urinary tract infections. BJU Int 2018;121:289-92. https://doi.org/10.1111/bju.14067

19. Arce JMV, Ballesteros CF, Hernández $\mathrm{H}$, et al. [Evaluación de una vacuna bacteriana (Uromune) en el tratamiento de las infecciones recurrentes del tracto urinario inferior.] Congrés Nacional Català d'Urologia 2013:1-14.

20. Lorenzo-Gómez MF, Martínez-Huélamo M, Valverde-Martinez LS, et al. Quality of life in patients with chronic prostatitis treated with elaborated polybacterial vaccine. International Continence Society 2018;250.

21. Ordaz-Jurado DG, Bonillo-García MA, Betancourt-Hernández J, et al. Does bacterial vaccine become clinically significant in neurogenic bladder in patients at clean intermittent catheterization? International Continence Society 2014;567.
22. Sánchez-Ramón $S$, Manzanares $M$, Candelas $G$. Mucosal anti-infections vaccines: Beyond conventional vaccines. Reumatol Clin 2020;16:49-55. https://doi.org/10.1016/i.reumae.2018.10.020

23. García-Agudo R, Redondo González 0, Cazalla Cadenas F, et al. [Vacunación sublingual con bacterias inactivadas en las infecciones urinarias de repetición de pacientes nefrológicos:experiencia en nuestro centro.] Congreso Nacional de la Sociedad Española de Nefrología 2015;539.

24. García-Ledesma P, Hernando $A$, Galan $M$, et al. [Análisis de nuestra experiencia en el tratamiento con la vacuna sublingual de bacterias inactivadas en pacientes con infecciones urinarias de repetición.] Congreso Nacional de la Sociedad Española de Nefrología 2016;1637.

25. Castro-Alonso C, Ruiz Millo 0, Gabibis Bernacer A, et al. [Efectividad de la vacunación bacteriana individualizada para prevenir infecciones urinarias de repetición en pacientes con ERC.] Congreso Nacional de la Sociedad Española de Nefrología 2016;1686.

26. Shabaka A, Zapata N, Santiago JL, et al. Clinical and immunological response to sublingual vaccination for the prevention of recurrent urinary tract infections in kidney transplant patients: Results after 1 year of followup. Transplantation 2018;102:S320. https://doi.org/10.1097/01.tp.0000543044.21389.51

27. Ochoa-Grullón J, Guevara K, Guzmán-Fulgencio M, et al. Polybacterial mucosal stimulation in lymphoproliferative syndromes with recurrent infections: A new complementary strategy. Eur Acad Allergy Clin Immunol 2017;576.

28. Lorenzo-Gómez MF, Padilla-Fernández B, González-Casado I, et al. The impact of the use of vaccine against recurrent urinary tract infection in frail elderly patients. International Continence Society 2018; Abstract 609

29. Padilla-Fernandez B, González Casado I, de Dios Hernández JM, et al. [Autovacuna frente a vacuna polibacteriana elaborada en el manejo de la infección urinaria en el anciano frágil.] Confederación Americana de Urología 2019;094.

30. Martinez-Camacho MA, Escuer Morell MJ, Royo Gomez GF, et al. [Profilaxis inmunoactiva para la prevención de las infecciones del tracto urinario de repetición.] Asociación Española de Pediatría 2015;C110.

31. Lorenzo-Gómez MF, Collazos Robles RE, Virseda Rodriguez AJ, et al. Urinary tract infections in women with stress urinary incontinence treated with transobturator suburethral tape and benefit gained from the sublingual polibacterial vaccine. Ther Adv Urol 2015;7:180-5. https://doi.org/10.1177/1756287215576648

32. Kraan H, Vrieling H, Czerkinsky C, et al. Buccal and sublingual vaccine delivery. J Control Release 2014;190:580-92. htrps://doi.org/10.1016/i.jonrel.2014.05.060

33. Czerkinsky C, Cuburu N, Kweon MN, et al. Sublingual vaccination. Hum Vaccin 2011;7:110-4. https://doi.org/10.4161/hv.7.1.13739

34. Cuburu N, Kweon MN, Song JH et al. Sublingual immunization induces broad-based systemic and mucosal immune responses in mice. Vaccine 2007;25:8598-610. https://doi.org/10.1016/i.vaccine.2007.09.073

35. Benito-Villalvilla C, Cirauqui C, Diez-Rivero CM, et al. MV140, a sublingual polyvalent bacterial preparation to treat recurrent urinary tract infections, licenses human dendritic cells for generating Thl, Th17, and IL-10 responses via Syk and MyD88. Mucosal Immunol 2017;10:924-35. https://doi.org/10.1038/ mi.2016.112

36. Saz-Leal P, Wang C, Ligon ML, et al. Immunological mechanisms of MV140, a polybacterial vaccine to prevent urinary tract infections. Optimmunize 2020;13.

Correspondence: Dr. J. Curtis Nickel, Department of Urology, Queen's University, Kingston, ON, Canada; in@queensu.ca

To answer the multiple-choice questions associated with this article, go to: www.cuasection3credits.org/cuajaugust2020. This program is an Accredited Self-Assessment Program (Section 3) as defined by the Maintenance of Cerrification Program of The Royal College of Physicians \& Surgeons of Canada, and approved by the Canadian Urological Association. Remember to visit MAINPORT (www.mainport.org/mainport/) to record your learning and outcomes. You may claim a maximum of 1 hour of credit. 